\title{
Preliminary Archaeopetrological Study of the Lithic Industry From the l'Hort de la Boquera Rock Shelter (Margalef de Montsant, Tarragona, Spain): Applying Mineralogical and Geochemical Techniques
}

\author{
Mar Rey-Soléa, Maria Pilar García-Argüelles ${ }^{b}$, Jordi Nadal ${ }^{c}$, Xavier \\ Mangado $^{d}$, Anders Scherstén ${ }^{e}$ and Tomas Næraa ${ }^{\natural}$
}

The l'Hort de la Boquera site is located in the northeastern part of Iberia and its stone tool assemblage includes up to 25,000 flint artefacts. This is the first approach to the analysis of the raw material through an archaeopetrological study. Results were obtained by use of mineralogical techniques: macroscopic and petrographic analysis, Scanning Electronic Microscopy (SEM), Micro-Raman and X-Ray diffraction (XRD); additionally, Laser Ablation Inductively Coupled Plasma Mass Spectrometry was applied.

It has been possible to discriminate at least four flint categories, the 'Evaporitic flint type' (with two local subvarieties - 'Common evaporitic' and 'Garnet' varieties) that comes from local outcrops of the Ulldemolins Complex, and two flint types that had their origin further afield: the 'Charophyta flint type' (coming from the Torrente de Cinca Unit) and the 'Dark flint type' (from the La Serra Llarga Formation).

These results make this study the most comprehensive analysis of raw materials that has been carried out in the area so far.

KEY-WORDS: archeopetrology, flint, raw materials, northeastern Iberia, Hort de la Boquera

\footnotetext{
a Seminari d'Estudis i Recerques Prehistòriques (SERP), Dept. Història i Arqueologia, Universitat de Barcelona, C/Montalegre, 6, o80oI, Barcelona, Spain, e-mail: mreysole@ub.edu; ORCID: 0000-0002-7387-0459

b Seminari d'Estudis i Recerques Prehistòriques (SERP), Dept. Història i Arqueologia, Universitat de Barcelona, C/Montalegre, 6, 080oI, Barcelona, Spain, e-mail: garciaarguelles@ub.edu; ORCID: 0000-0002-2582-9734

c Seminari d'Estudis i Recerques Prehistòriques (SERP), Dept. Història i Arqueologia, Universitat de Barcelona, C/Montalegre, 6, 080oI, Barcelona, Spain, e-mail: jordinadal@ub.edu; ORCID: 0000-0003-I305-6I7X

d Seminari d'Estudis i Recerques Prehistòriques (SERP), Dept. Història i Arqueologia, Universitat de Barcelona, C/Montalegre, 6, 080oI, Barcelona, Spain, e-mail: mangado@ub.edu; ORCID: 0000-0002-3594-0794

e Department of Geology, University of Lund, Sölvegatan I2, 223 62, Lund, Sweden, e-mail: anders.schersten@ geol.lu.se; ORCID: 0000-0002-2105-6172

f Department of Geology, University of Lund, Sölvegatan I2, 223 62, Lund, Sweden, e-mail: tomas.naeraa@geol. lu.se; ORCID: 0000-000I-9770-718I
} 
$24 \mid$ Rey-Solé et al

\section{INTRODUCTION AND OBJECTIVES}

The archaeological site of l'Hort de la Boquera, dated to the Final Upper Magdalenian (from I2,25O \pm 60 BP to II,85O \pm 45 BP and II,775 \pm 45 BP), is located in Margalef de Montsant (Priorat, Tarragona, Northeastern Iberia; García-Argüelles et al., 20I4: 250; Fig. I). It is a small rock shelter which is the result of the erosion of the tertiary Oligocene conglomerates on the valley edge and has a very homogeneous stratigraphy composed by limestone fragments, sand and pebbles.

The Seminari d'Estudis i Recerques Prehistòriques SERP (UB) has been working in there since 1998, revealing it as a very prolific site with a specific knapping area and a copious assemblage of lithic material comprising 24,I08 flint remains, 976 retouched tools and 269 cores and core fragments (Rey-Solé 20I6: 23I).

One of the aims of this research is to discover the provenance of the different flint varieties recovered in the rock shelter in order to study the degree to which the prehistoric communities using the site had a knowledge of the surrounding environment and determine their mobility. It was expected that the use of different mineralogical and geochemical techniques would allow this goal to be reached and allow the differentiation of the flint samples.

\section{MATERIAL AND METHODS}

\section{The archaeopetrological method}

The first step in the research on the raw materials consists of the implementation of a petrological study of the archaeological lithic industry, from the macroscopic level to elemental level, intended to categorize the different types of flint. This would also allow the plotting of the geographical location of the different outcrops on the map, which is a very important step in determining the prehistoric availability of flint in the area. This will allow a picture to be built of the origin of the raw material used on the site (Mangado 2005).

\section{Laboratory analysis: macroscopic and microscopic approach}

The methodological approach consisted in the textural analysis of all the samples. The samples were first analysed macroscopically by the naked eye and also using a binocular magnifier (COlympus KL 1500 LCD with (OOlympus TH4-200 source of light) examining a total of 25,353 lithic tools, flint flakes and cores and also 27 geological samples.

Secondly, I9 thin sections have been made from the most representative archaeological and geological samples in order to analyse them, looking for their most characteristic textural characteristics (Luedtke 1992), with an optical microscope (COlympus $\mathrm{BX}_{4 \mathrm{I}}$ with (O)lympus SC-30 camera). 
We wanted to go a step forward applying other mineralogical techniques, such as Micro-Raman spectroscopy (Dubessy et al., 2012), Scanning Electronic Microscopy (Bull 1983) and X-ray diffraction analysis (Bustillo and La Iglesia 1979). Finally, to resolve particular problems we have chosen Inductively Coupled Plasma Mass Spectrometry Laser Ablation.
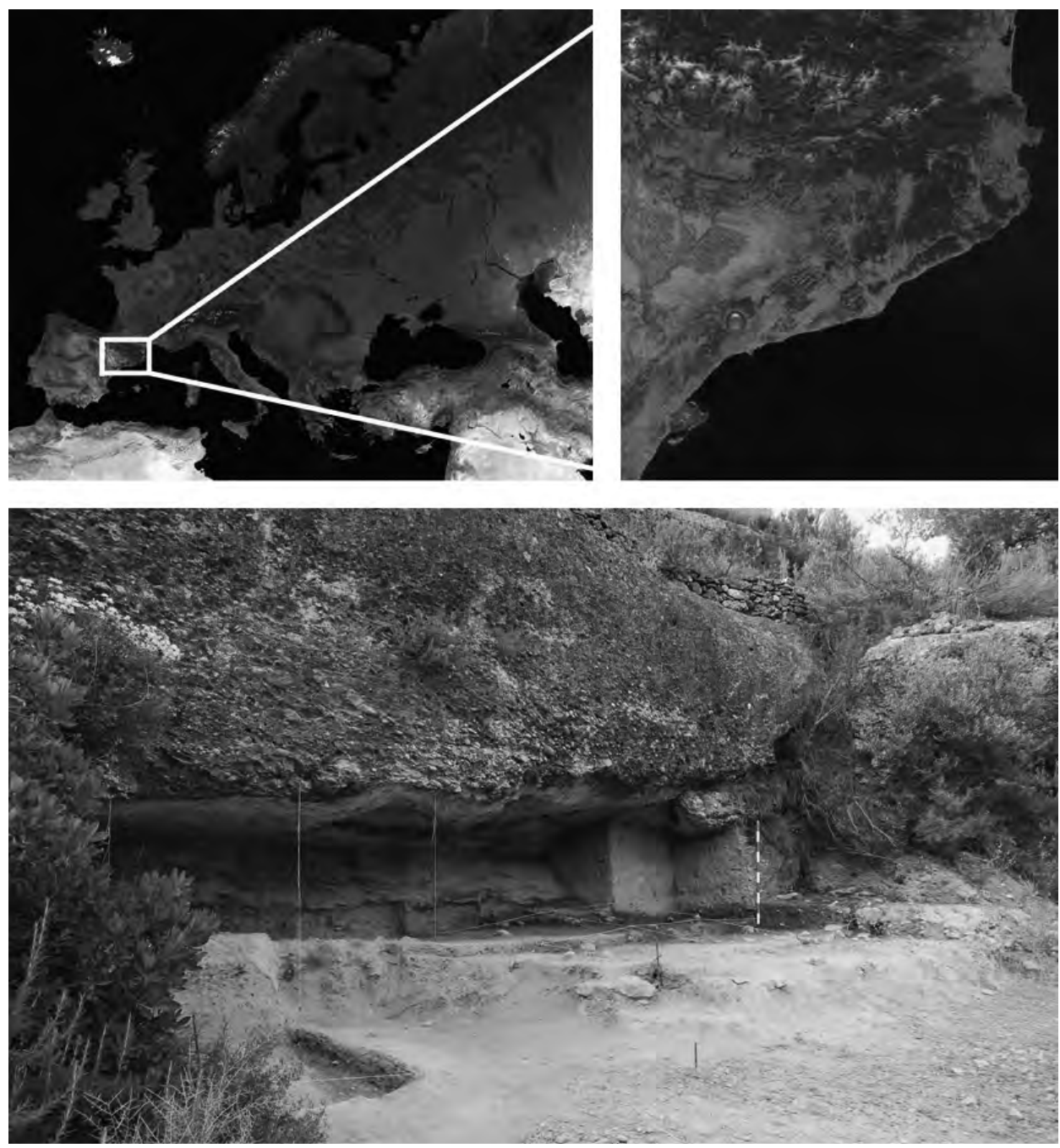

Fig. 1. General view of the location of the l'Hort de la Boquera site. Recent image of the rock shelter. Photo: M. P. García-Argüelles and M. Rey-Solé. 
$26 \mid$ Rey-Solé et al

\section{Fieldwork}

A total of 27 flint outcrops related to the archaeological site have been visited and documented by taking pictures, writing down all the characteristics of the outcrop and picking up enough flint samples to analyse. The analysis of these flint outcrops and their comparison with the raw materials from the rock shelter have led to the preliminary identification of the potential sources of supply of the Upper Palaeolithic and Epipalaeolithic groups.

\section{RESULTS}

Flint types: characteristics and abundance at the site

The combination of techniques allowed us to discriminate at least three types of flint (Rey-Solé 20i6).

- 'Evaporitic flint type': this type has two subvarieties:

a) 'Common evaporitic': characterized by a varied colouration due to impurities, medium to coarse grain and the presence of gypsum lenticles. Low to average quality type and with a very high degree of weathering (white patina). This is represented by 950 (97.33\%) stone tools, 24,008 (99.60\%) flint flakes and all the cores (269).

b) 'Garnet subvariety': this kind of flint is garnet and white coloured, opaque, it is very fine grained with no impurities, and has good qualities for knapping. It is found in spots in the 'common evaporitic' flint. It is represented by four $(0.40 \%)$ stone tools and $60(0.25 \%)$ flint flakes.

- The 'Carophyta flint type': this kind of flint is characterized by its great heterogeneity and its high quality, but the most revealing characteristics are the Liesegang rings and the algal fragments of Gyrogona charophyta found in it. It is represented by 18 (I.84\%) stone tools and 21 (0.08\%) flint flakes.

- The 'Dark flint type': this type of flint is black coloured and very good for knapping; microscopically it is characterized by a cryptoquartz matrix with the presence of isolated carbonated remains, some rhomboidal crystals and casts of indeterminate fossils. It is represented by four (0.40\%) stone tools and 19 (0.07\%) flint flakes (Fig. 2).

\section{Raw material provenance}

The characterization of archaeological and geological samples allowed us to match them in order to assign a particular origin to the discriminated types of flint. The deployment of techniques was differentially applied depending on the complexity of this discrimination (Rey-Solé 20ı6: 408-409). 
EVAPORITIC FLINT TYPE

Common

evaporitic subvariety

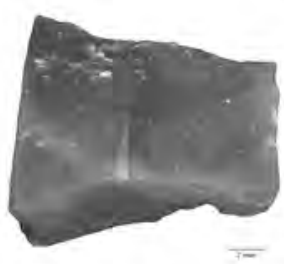

Garnet

flint subvariety

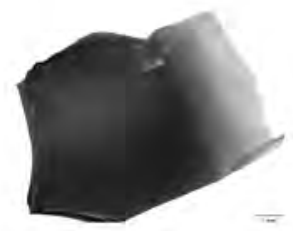

CHAROPHYTA FLINT TYPE

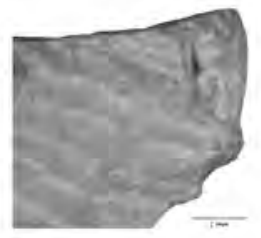

DARK FLINT TYPE

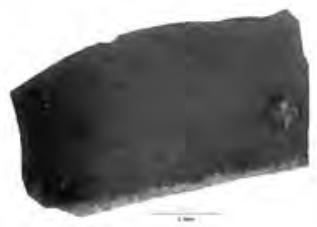

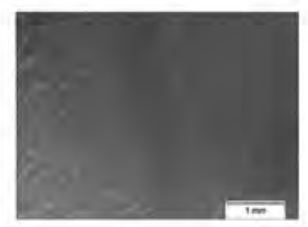
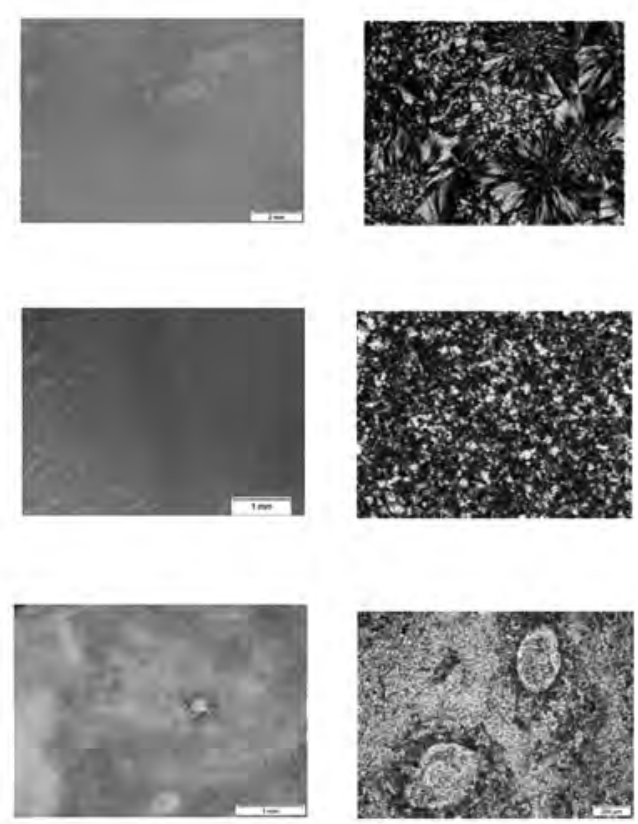

\section{MACROSCOPY MICROSCOPY}
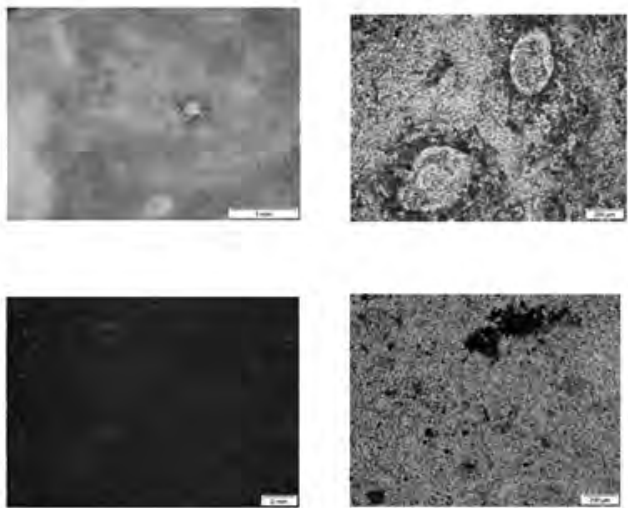

Fig. 2. The identified flint types with macroscopic and microscopic views. Computer graphics: M. Rey-Solé.

- The 'Evaporitic flint type' was compared with an autochthonous type of flint coming from the Ulldemolins Complex (lower-middle Eocene). This consists of sandstones and clays with gypsum and flint formation (Colombo 1986: 66-67), and outcrops are located between $\mathrm{I} 3$ to $20 \mathrm{~km}$ from the site. This big complex is composed by at least seven different flint outcrops from seven different gypsum layers so one of the aims was to know if there was a preferred outcrop to obtain this kind of raw material.

\footnotetext{
I Estimated distances by walking on the Montsant river bank, from the neareast outcrop to the farest outcrop.
} 
The flint recovered in all of those seven outcrops have very similar characteristics, both macroscopically and microscopically, so the next step was the application of Scanning electronic microscope, Micro-Raman spectroscopy and X-ray diffraction analyses. This set of techniques proved not to be useful to our objective thus Inductively Coupled Plasma (LA-ICP) Mass Spectrometry was applied in order to know the concentration of trace elements to make easier to distinguish samples.

The LA-ICP Mass Spectrometer (@Bruker Aurora M9o) was programmed to analyze 33 different elements, testing 3 spots per sample (IIO $\mu \mathrm{m}$ ) at seven $\mathrm{Hz}$ and four $\mathrm{J} /$ $\mathrm{cm}^{2}$ of frequency (Rey-Solé et al., 20I7). The results obtained allowed us to establish two different groups with similar element concentrations, showing several geochemical relations between the majority of archaeological and geological samples. One group established a relationship between all the geological outcrops from Ulldemolins Complex with three archaeological samples and the other group established a relationship between three particular geological outcrops from Ulldemolins complex with two archaeological samples. There are three archaeological samples that seem to have a different geochemical origin than the others so we could conclude that simultaneous and different flint catchment points existed in the Ulldemolins Complex, even undiscovered ones (Rey-Solé et al., 20I7; Fig. 3).

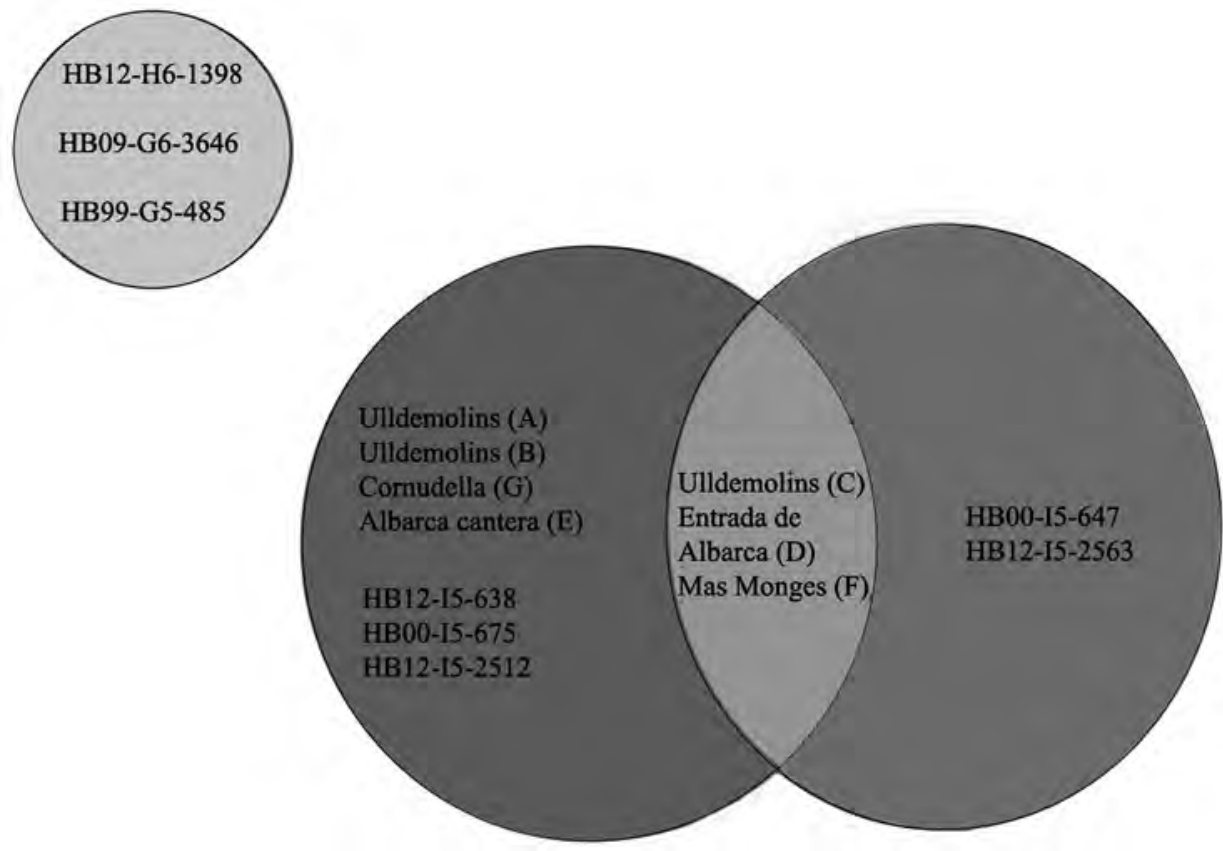

Fig. 3. Geochemical proximity of samples. Drawn: M. Rey-Solé. 
- The 'Charophyta flint type': the geological surveys and the combination of techniques (macroscopic and petrographic) allowed us to match this kind of flint with an allocthnous raw material coming from Torrente de Cinca-Alcolea de Cinca Unit (Lower Miocene - Chattian- Aquitanian). This is a sandy and marly bioclastic carbonate with gastropoda and characae fragments with flint nodule formation located $75 \mathrm{~km}$ from the rockshelter (Rey-Solé 2016: 255; Fig. 4).

- The 'Dark flint type': the geological surveys and the combination of other techniques (macroscopic and petrographic) allowed us to match this kind of flint with an allochthonous raw material coming from La Serra Llarga (Rupelian), which is a micritic limestone formation, located at nearly $80 \mathrm{~km}$ from the archaeological site. It has at least three different outcrops but only two provide this kind of flint. With the macroscopic and microscopic approach, we assume that they were the same type of flint because both matrix and cortex have the same characteristics (Rey-Solé 20r6: 256; Fig. 5).
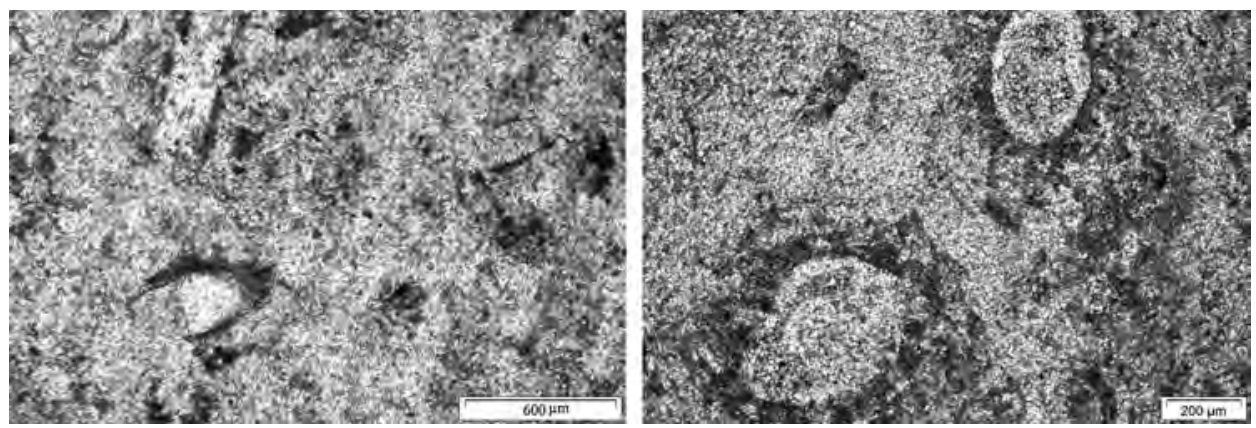

Fig. 4. Sample comparison. Left: geological sample from Torrente de Cinca Unit $(600 \mu \mathrm{m})$. Right: archaeological sample classified as 'Charophyta flint type' $(200 \mu \mathrm{m})$ Optical microscope. Photo: M. Rey-Solé.
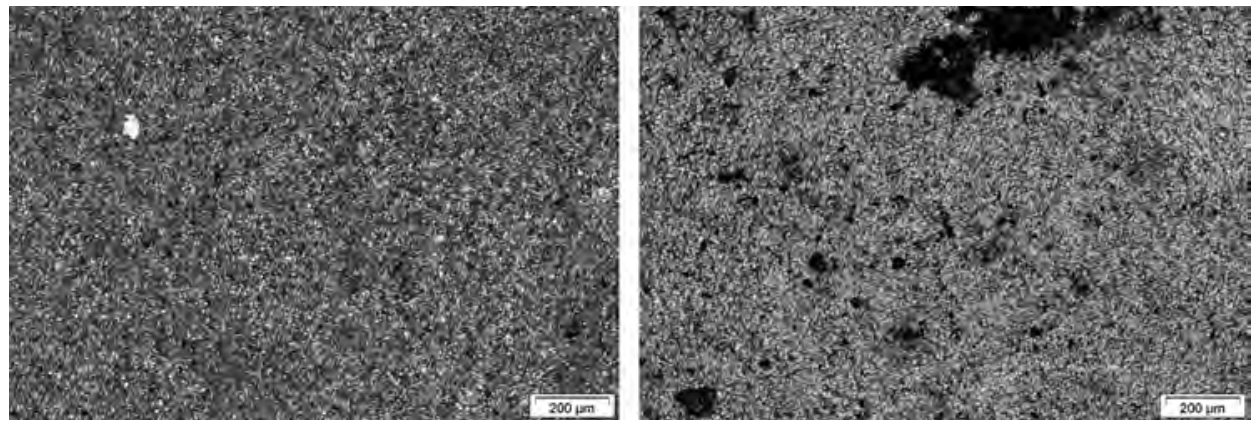

Fig. 5. Sample comparison. Left: geological sample from La Serra Llarga Formation (200 $\mu \mathrm{m})$.

Right: archaeological sample classified as 'Dark flint type' $(200 \mu \mathrm{m})$. Optical microscope. Photo: M. Rey-Solé. 
$30 \mid$ Rey-Solé et al

\section{Catchment proposal hypotheses}

At least three hypotheses about the exploitation of the siliceous raw material are possible. First, the prehistoric communities could remove the flint nodules directly from the host rock in primary outcrops, but this probably is not the source of the two allochthonous types of flint.

Secondly, and one of the strongest hypothesis, is the natural transport of flint nodules through the hydrographic network - rivers and its tributaries - where raw material could have been eroded from the riverbanks and terraces. This hypothesis could fit with all flint types recovered but it is strongest theory for 'Evaporitic flint type'. The Montsant river is located only Ioo meters from the rock shelter, and the evaporitic flint

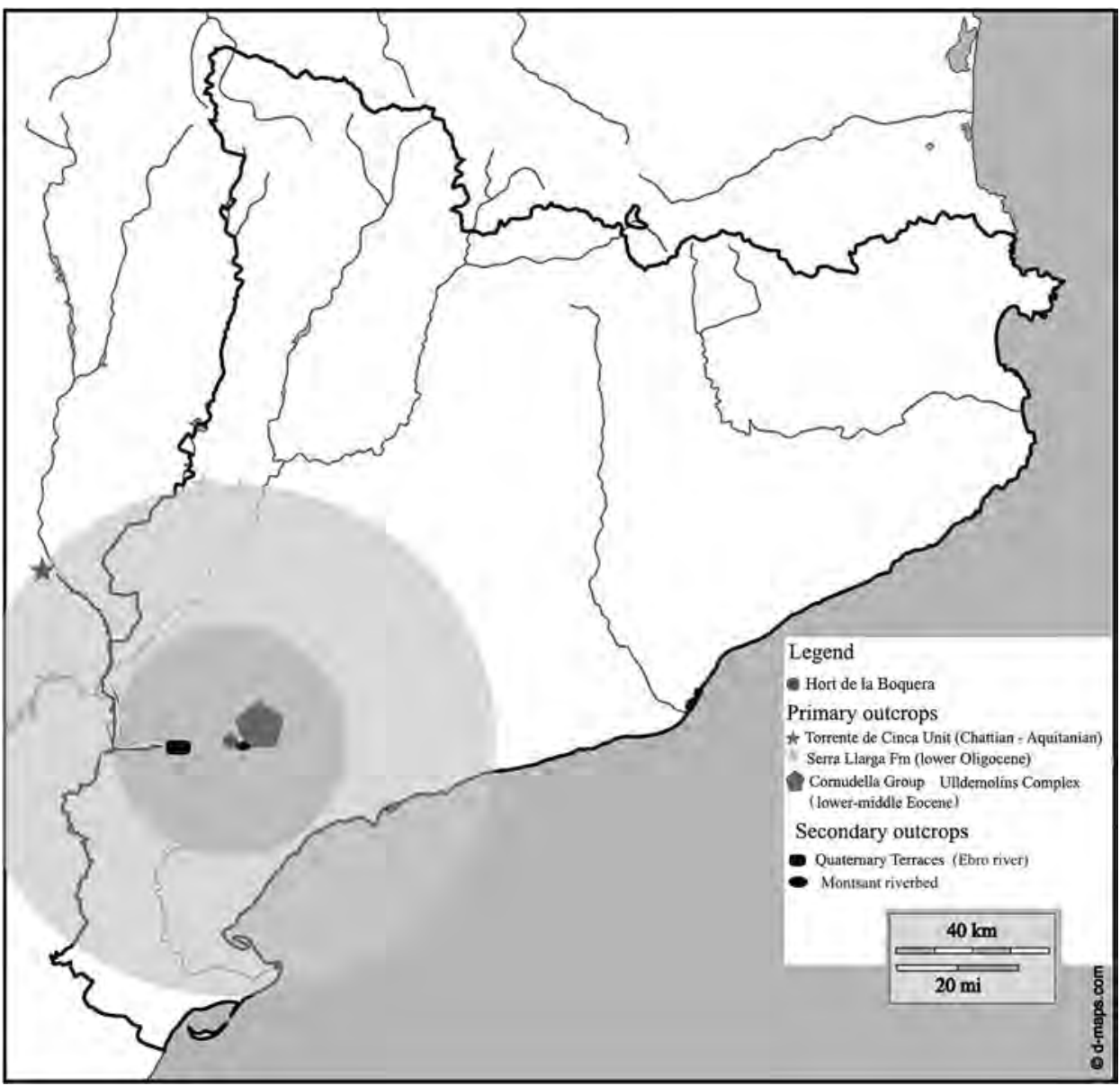

Fig. 6. Map relating the L'Hort de la Boquera site with the different primary and secondary outcrops of siliceous material. D-Maps modified: M. Rey-Solé. 
nodules could be found in the river bed, but also the site is located above one of its terraces (T2; García-Argüelles et al., 1993: 495). This is not the only archaeological site located in the region of the Montsant terraces, there are other examples as El Planot, Els Colls, l'Hort d'en Marquet and El Filador, and all of them are in a chronocultural correlation with these terraces (García-Argüelles et al., 1993).

Regarding the minor varieties, the Ebro quaternary terraces, located at $30 \mathrm{~km}$ from the site, could provide the prehistoric communities with the other non-local types of flint (the 'Charophyta flint type' and the 'Dark flint type'). It is well-known that raw material could travel tens or hundreds of kilometres from its primary origin (Fig. 6).

Finally, the third hypothesis involves contacts with other human groups, when raw materials could have been exchanged by different prehistoric communities in the vicinity of l'Hort de la Boquera. This hypothesis fits well for 'Charophyta flint type' and 'Dark flint type' where lithic flakes and cores have not been found so far, strongly suggesting that the lithic tools could have come to the site already manufactured.

Other nearby Final Palaeolithic and Epipalaeolithic sites cited above located in the Montsant Valley, such as El Filador, Els Colls, L'Hort d'en Marquet and El Planot (García-Argüelles et al., 20I4a) do not yet have an exhaustive analysis of the lithic assemblages or studies of the provenance of the raw materials. It is true that the collections of lithic raw materials from these sites have big similarities to the l'Hort de la Boquera assemblage, but a thorough comparison between these groups is needed to obtain a regional picture and better understand some human behaviours regarding the procurement of lithic material.

\section{CONCLUSIONS}

The application of different mineralogical and geochemical techniques to the material from the l'Hort de la Boquera rock shelter has allowed us to discriminate and characterize the three different types of flint ('Evaporitic', with the 'Common flint' and 'Garnet' subvarieties, the 'Charophyta' and 'Dark flint type'). The deployment of several techniques - mineralogical and geochemical - have led us to learn which are the most adequate techniques to apply. The 'Evaporitic flint type' is an autochthonous raw material that comes from outcrops about $20 \mathrm{~km}$ from the site. The 'Charophyta flint type' and the 'Dark flint type' come from outcrops nearly $75 \mathrm{~km}$ and about $80 \mathrm{~km}$ from the site respectively. Knowing the provenance of the raw material used in l'Hort de la Boquera allows the construction of hypotheses about the site's raw material supply. Although there is a major type of local flint used for the lithic industry, the two subvarieties of the 'Evaporitic flint type', there is also evidence of the less frequent use of two other varieties, the 'Charophyta flint type' and the 'Dark flint type' which do not seem to occur in local outcrops. 
$32 \mid$ Rey-Solé et al

So far we can state that the riverbanks and their terraces are an excellent location for obtaining siliceous raw materials, in this case, the Montsant river and Ebro quaternary terraces. Greater independence and self-sufficiency is reflected by the lithic assemblages of the prehistoric communities from l'Hort de la Boquera rock shelter in addition to a considerable knowledge of their environment.

\section{ACKNOWLEDGEMENTS}

The analyses were performed in the Museo Nacional de Ciencias Naturales-CSIC (Madrid) and Lund University ${ }^{40} \mathrm{Ar} /{ }^{39} \mathrm{Ar}$ Geochronology Lab (Lund, Sweden). This research was supported by grants from HAR2OII 26I93 and SGR 20I4-Io8 projects and FPI programme (Ministerio de Economía y Competitividad, Gobierno de España).

\section{REFERENCES}

Bull, P. A. 1983. Procedures in enviromental reconstruction by SEM analysis. In G. De G. Sieveking and M.B. Hard (eds), The scientific study of flint and chert, 452 proceedings of the fourth International Flynt Symposium, 221-225. Cambridge.

Bustillo, M. A. and La Iglesia, A. 1979. Sílex: Relación entre índices de cristalinidad y ambientes de sustitución. Boletín Geológico y Minero 90, fasc. 6: 86-92.

Colombo, F. 1986. Estratigrafía y sedimentologia del paleogeno continental del borde meridional occidental de los Catalánides (Provincia de Tarragona, España). Cuadernos de Geología Ibérica l: 55-II5.

Dubessy, J., Caumon, M. C. and Rull, F. (eds) 2012. Applications of Raman Spectrometry to Earth Sciences and Cultural Heritage. In G. Ferraris (Series Editor), European Mineralogical Union Notes in Mineralogy. London.

García-Argüelles, M. P., Serrat, P. and Bergadà, M. M. 1993. Las terrazas del curso medio del río Montsant (Priorato, Tarragona) y su relación con los asentamientos prehistóricos. In El Cuaternario en España y Portugal I, 493-499. Madrid.

García-Argüelles, P., Nadal, J. and Fullola, J. M. 20r4a. El Valle de Montsant (Priorato, Tarragona), un núcleo clave de la prehistoria del NE peninsular. Los cazadores recolectores del Pleistoceno y del Holoceno en Iberia y el estrecho de Gibraltar: estado actual del conocimiento del registro arqueológico. Servicio de publicaciones de la Universidad de Burgos I: 208-217. Burgos.

García-Argüelles, M.P., Nadal, J., Fullola, J.M., Bergadà, M.M., Domingo, I., Allué, E. and Lloveras, L. 20I4b. Nuevas interpretaciones del Paleolítico Superior Final de la Catalunya meridional: el yacimiento de l'Hort de la Boquera. Trabajos de Prehistoria 7I (2): 242-26o.

Luedtke, B. E. 1992. An archaeologist's guide to chert and flint. Los Angeles.

Mangado, X. 2005. La caracterización y el aprovisionamiento de los recursos abióticos en la Prehistoria de Cataluña: las materias primas siliceas del Paleolitico Superior Final y el Epipaleolitico. Oxford. British Archaeological Reports, International Series I420.

Rey-Solé, M. 2016. Determinación arqueopetrológica y territorial de los materiales siliceos entre el sur de Tarragona y el norte de Castellón. Unpublished $\mathrm{PhD}$ thesis, University of Barcelona. 
Preliminary Archaeopetrological Study of the Lithic Industry From the l' Hort de la Boquera Rock Shelter

Rey-Solé, M., Scherstén, A., Naeraa, T., Olausson, D. and Mangado, X. 20I7. Siliceous raw materials exploitation at Hort de la Boquera site (Margalef de Montsant, Tarragona, Spain): first approaches on LA-ICP-MS analysis. In T. Pereira, N. Bicho and X. Terrades (eds), Raw materials exploitation in Prehistory: sourcing, processing and distribution, 235-249. Cambridge. 
